\title{
ENHANCEMENT OF BUFFER STRIPS CAN IMPROVE PROVISION OF MULTIPLE ECOSYSTEM SERVICES
}

\author{
Robin J. Blake', Duncan B.Westbury², Ben A.Woodcock ${ }^{3}$, Peter Sutton ${ }^{4}$ and Simon G. Potts' \\ 'Centre for Agri-Environmental Research, School of Agriculture, Policy and Development, University of Reading, \\ Earley Gate, Reading, RG6 6AR, UK; ' Institute of Science \& the Environment, University of Worcester, Henwick \\ Grove,Worcester,WR2 6AJ, UK; ${ }^{3}$ NERC Centre for Ecology \& Hydrology, Crowmarsh Gifford, Wallingford, \\ Oxon OXI0 8BB, UK; ${ }^{4}$ Syngenta, Jealott's Hill International Research Centre, Bracknell, Berkshire, RG42 6EY, UK \\ Corresponding Author: Robin Blake. E-mail: robin.blake@syngenta.com; Tel. +44(0) I 344 4I 3898. Syngenta, \\ Jealott's Hill International Research Centre, Bracknell, Berkshire, RG42 6EY, UK
}

Keywords: Agri-environment schemes, bumblebees, butterflies, buffer strips, ecosystem services, graminicide, spiders

\section{Introduction}

Farmland invertebrates play a pivotal role in the provision of ecosystem services, i.e. services that benefit humans. For example, bumblebees, solitary bees and honeybees, are crucial to the pollination of many of the world's crops and wildflowers, with over $70 \%$ of the world's major food crops dependent on the pollination services provided by these insects (Klein et al., 2007). The larvae of some butterfly species are considered to be pests; however, together with moth and sawfly larvae, they represent a key dietary component for many farmland birds. Spiders and ground beetles predate on crop pests including aphids, whilst soil macrofauna such as earthworms are vital for soil fertility services and nutrient recycling.

Despite their importance, population declines of invertebrates have been observed during the last sixty years in the UK and NW Europe. For example, seven UK bumblebee species are in decline, and in the last 20 years, the species Bombus subterraneus (short-haired bumblebee) has become extinct, whilst there was a $54 \%$ decline in honeybee colony numbers in England from 1985 to 2005 (Potts et al., 2010).

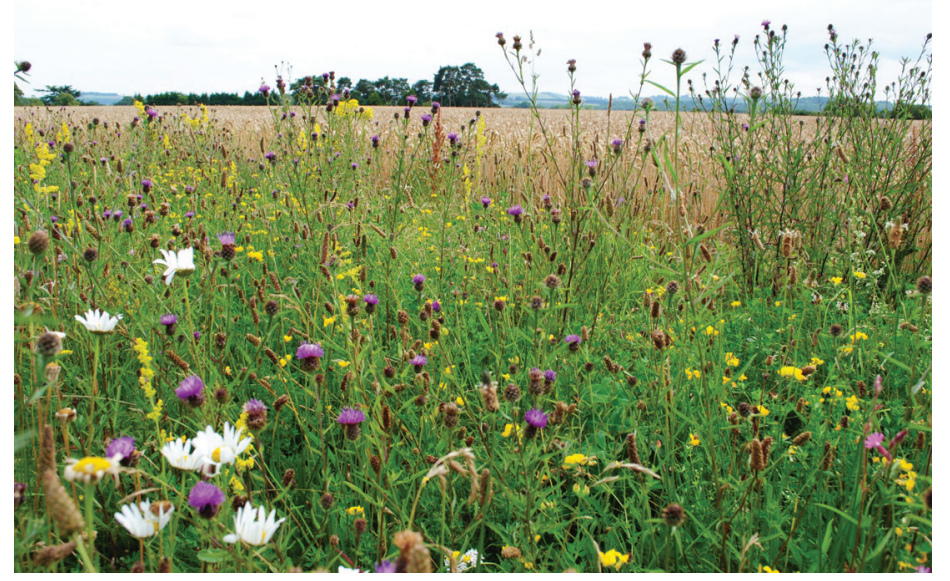

Figure I. Grass buffer strip enhanced with wildflowers.
Comparable trends have been documented for butterflies with a $23 \%$ decline in UK farmland species such as Anthocharis cardamines (orange tip) between 1990 and 2007 (Butterfly Conservation et al., 2009). These declines have been widely attributed to the modern intensive arable management practices that have been developed to maximise crop yield. For example, loss and fragmentation of foraging and nesting habitats, including species-rich meadows and hedgerows, have been implicated in the decline of bees and butterflies (Feber et al., 1996; Pywell et al., 2005). Increased use of herbicides and fertilisers has caused detrimental effects on many plant species with negative consequences for predatory invertebrates such as spiders and beetles which rely on plants for food and shelter (Marshall et al., 2003)

\section{Agri-environment schemes}

Agri-Environment Schemes (AES) have been developed across Europe in response to losses in farmland biodiversity and provide financial incentives in return for environmentally sensitive farming. Whilst options exist within AES aimed at enhancing invertebrates such as the sowing of nectar-rich flower mixtures to increase the availability of pollen and nectar foraging resources, or the establishment of beetle banks to promote spiders and beetles, uptake has been low (Natural England, 2009). A popular option is the establishment of perennial grass buffer strips with over 29,000 ha currently under UK AES agreements (Natural England, 2009). These strips can help protect sensitive areas of the field boundary such as hedgerows and watercourses from pesticide and fertiliser drift, and are important refuges for many insects and ground-nesting birds. However, the strips are typically established using only grasses, and tend to lack a wildflower component. Studies have demonstrated how cultivation of the buffer strip surface to create bare ground and application of a low dose of a graminicide (herbicide targeting grasses) to suppress competitive grasses can promote the development of sown wildflowers, benefitting a wider range of invertebrates (Gibson et al., 1992; Potts et al., 2007) (Fig. 1). The aim of this study was to investigate how the enhancement of existing grass buffer strips on arable farmland can be used to promote the abundance of bumblebees, butterflies and spiders, thereby supporting multiple ecosystem service providers. 


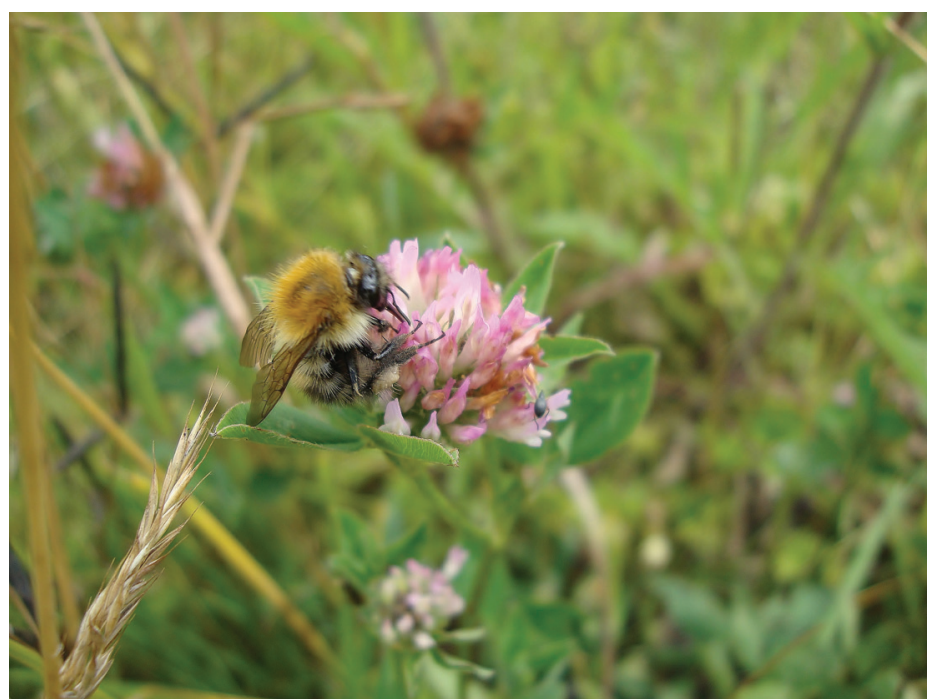

Figure 2. Bombus pascuorum (common carder-bee) on T. pratense (red clover).

\section{Managing existing buffer strips}

The study was initiated in spring 2008 when three treatments were applied to grass buffer strips that were established 3-5 years earlier on two arable farms in Berkshire, UK. Three replicate blocks each consisting of three treatment plots were established on the outer $4 \mathrm{~m}$ of existing $6 \mathrm{~m}$ grass buffer strips to investigate two management practices: (a) shallow cultivation to create bare ground into which wildflower seeds were sown; (b) graminicide (fluazifopP-butyl) application to reduce the competitive dominance of grasses. The three treatments were (1) control (existing grass buffer strip with no cultivation, seed or graminicide); (2) cultivation and seed only; and (3) cultivation, seed and graminicide. Cultivation was applied once in March 2008 with a power harrow to a depth of approximately $5 \mathrm{~cm}$ to break up the existing sward and create a seed bed. A perennial wildflower seed mixture containing nine species known to provide foraging resources for bumblebees and butterflies,

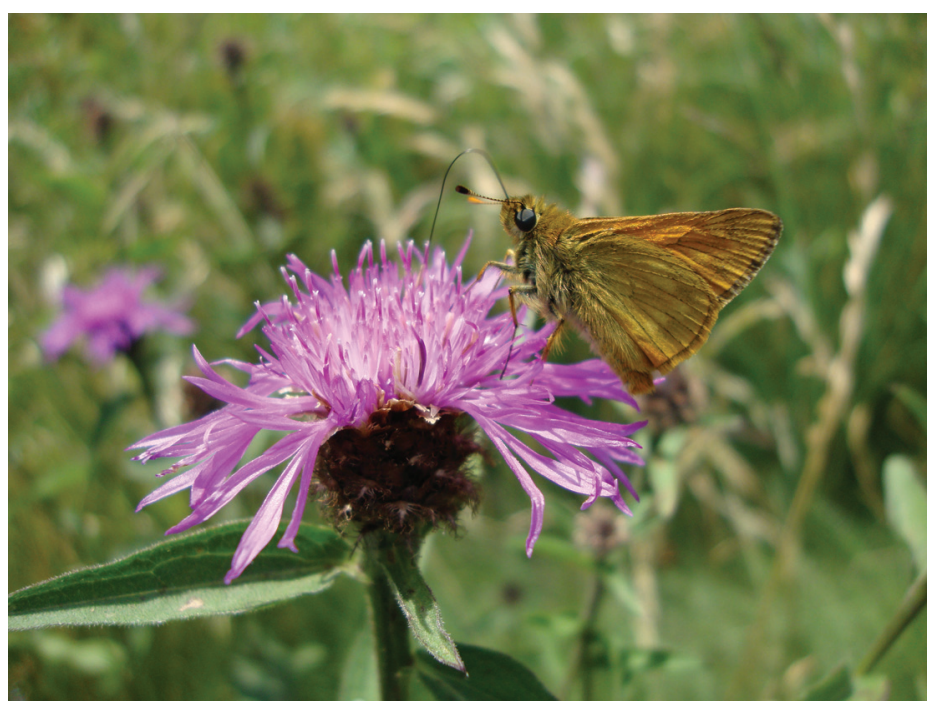

Figure 3. Ochlodes sylvanus (large skipper) on Centaurea nigra (common knapweed). and structural features for spiders, such as Trifolium pratense (red clover), was then sown at a total rate of $2.4 \mathrm{~kg} / \mathrm{ha}$ (Figs. $2,3 \& 4)$. The graminicide fluazifop-P-butyl (Fusilade Max $125 \mathrm{~g} / \mathrm{L}$ EC, Syngenta Crop Protection Ltd.) was sprayed once at a rate of $93.75 \mathrm{~g}$ ai/ha in April 2008 (recommended rate for grass control $125-375 \mathrm{~g} / \mathrm{ha}$ ).

Plant assessments were conducted during June 20082010 using $0.5 \times 0.5 \mathrm{~m}$ quadrats to assess both the percentage cover of the sown wildflower species, and all the grasses present. All species were identified and assigned a percentage cover value based on an eight point scale. The abundance of bumblebees and butterflies was recorded from monthly transect walks during April to September 2008-2010. Spiders were collected twice per year in 2008 and 2009 using a Vortis suction sampler, with adults identified to species. Percentage cover values of wildflowers and grasses, and abundance of bumblebees, butterflies and spiders were summed to provide total cover/abundance counts. All data were log-transformed $(\mathrm{LN}+1)$ and analysed in SAS 9.2 using general linear mixed models with repeated-measures.

\section{Results}

Significant treatment effects were observed for both the mean percentage sown wildflower cover $\left(F_{2,9.93}=17.79, P<0.001\right)$ and mean percentage grass cover $\left(F_{2,11.8}=9.61, P<0.001\right)$ (Fig. 5). Tukey's multiple comparison test revealed that Treatment 3 (cultivated, sown with wildflowers, and sprayed with graminicide) was associated with a significantly greater cover of sown wildflowers $(P<0.05)$, compared to Treatment 2 (cultivated and sown with wildflowers). There was a significant year effect for sown wildflower cover $\left(F_{2,18.1}=8.41, P<0.001\right)$ with greater values in 2009 and 2010 compared to 2008 ( $P$ $<0.05)$. Few sown wildflowers were observed in Treatment 1 (control). Grass cover was significantly lower in Treatment 3 compared to Treatment $1(P<0.05)$, and a significant year effect revealed greater values of grass cover $\left(F_{2,24.6}=9.47, P<\right.$ $0.001)$ in 2009 and 2010 compared to $2008(P<0.05)$.

Significant effects were observed for the abundance of bumblebees $\left(\mathrm{F}_{2,13.4}=12.94, P<0.001\right)$ and butterflies $\left(\mathrm{F}_{2,10.9}\right.$ $=11.14, P<0.01)$, with Tukey's test revealing higher abundances in Treatment 3 for both taxa (Fig. 6a and b). Treatment 3 was also associated with a significantly greater abundance of adult spiders $\left(\mathrm{F}_{2,8}=8.15, P<0.05\right)$ (Fig. $6 \mathrm{c}$ ), with a significant year effect $\left(\mathrm{F}_{1,8}=25.79, P<0.01\right)$ revealing greater abundances in year one (2008) compared to year two (2009).

\section{Discussion}

The greatest sown wildflower cover and lowest grass cover was observed in the treatment receiving a combination of cultivation and wildflower seed addition, coupled with application of the gramicide fluazifop-P-butyl (treatment 3). Shallow cultivation or scarification is a commonly used grassland restoration technique for creating gaps in swards, into which desirable species such as wildflowers can be introduced (Hofmann \& Isselstein, 2004). However, unless additional management is undertaken to reduce the levels of existing competitive species such as grasses, this cultivation is unlikely 


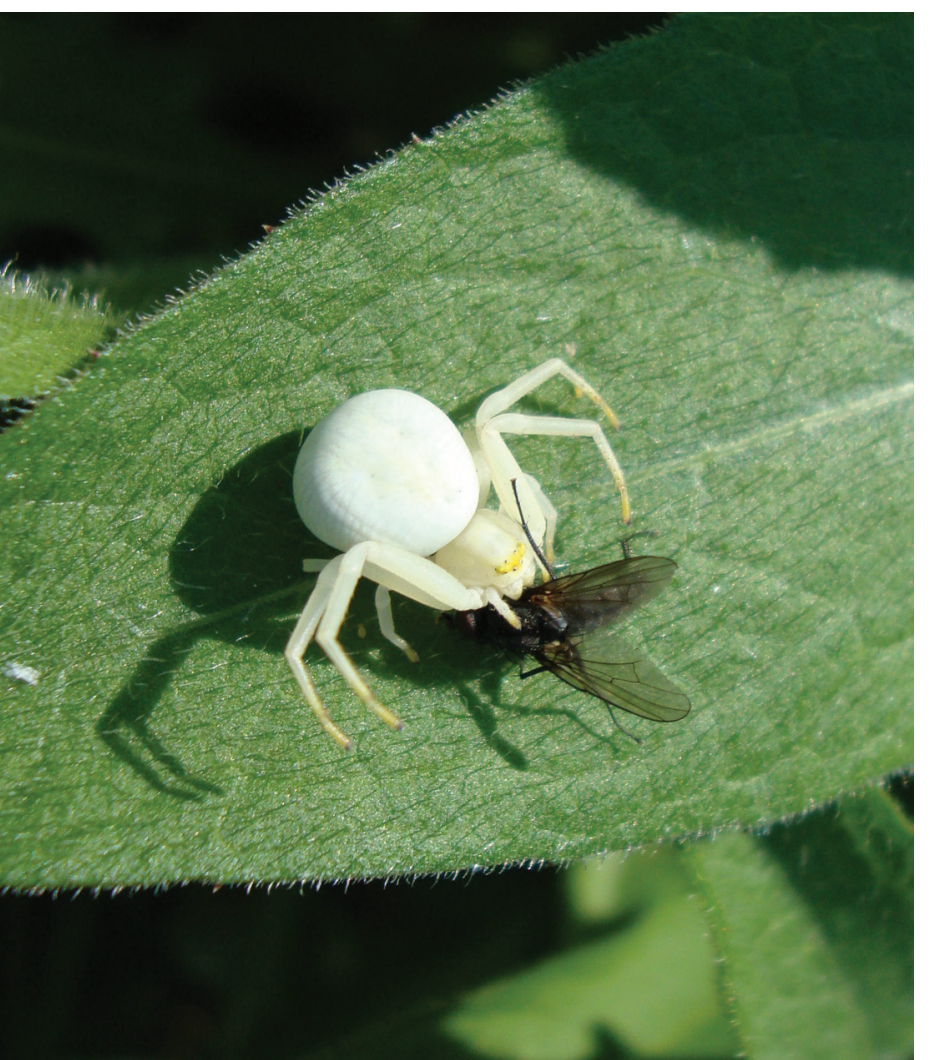

Figure 4. Crab spider (family Thomisidae).

(a)

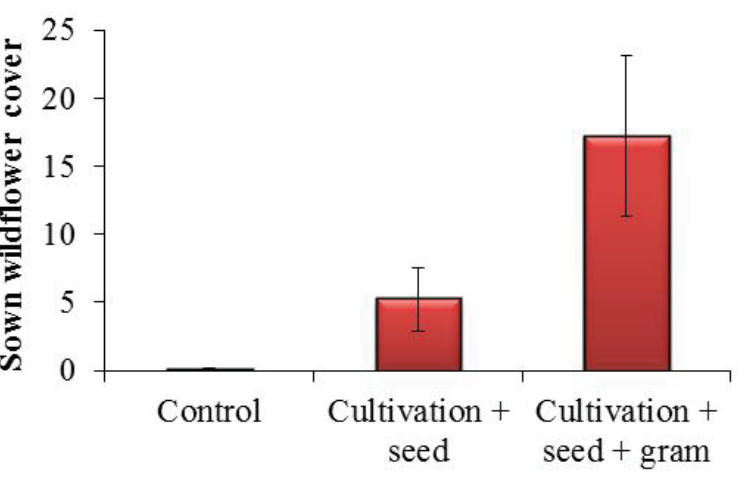

Treatment

(b)

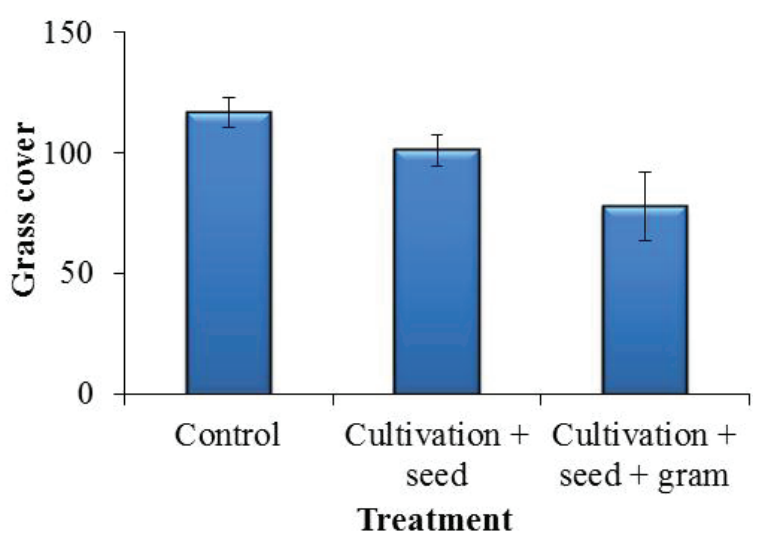

Figure 5. The response of mean plant cover to treatments from 2008 to 2010 (a) sown wildflowers ( \pm SE) (b) sown and unsown grasses ( \pm $\mathrm{SE})$. Gram = graminicide. Graphs show overall treatment responses across both sites and all years (untransformed data). Based on post-hoc Tukey's tests. (a) Bumblebees

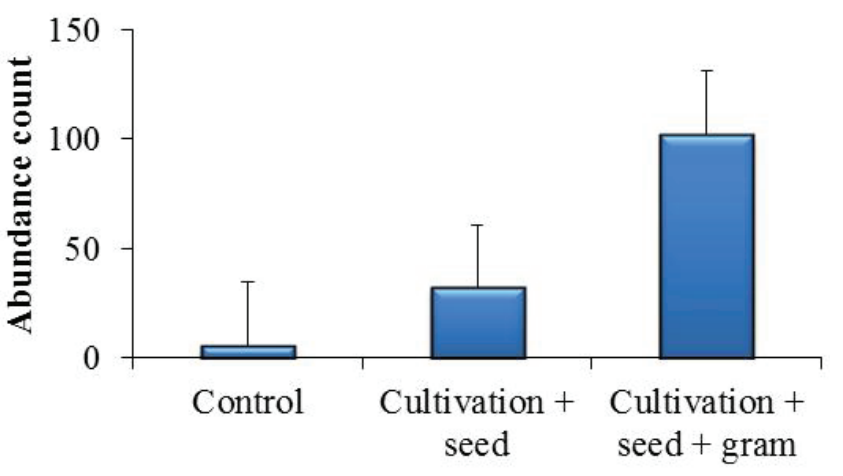

Treatment

(b) Butterflies

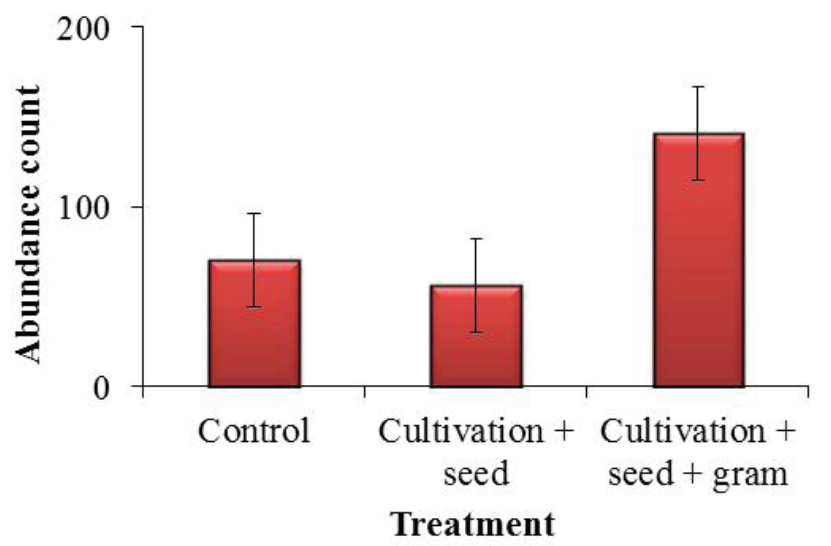

(c) Spiders

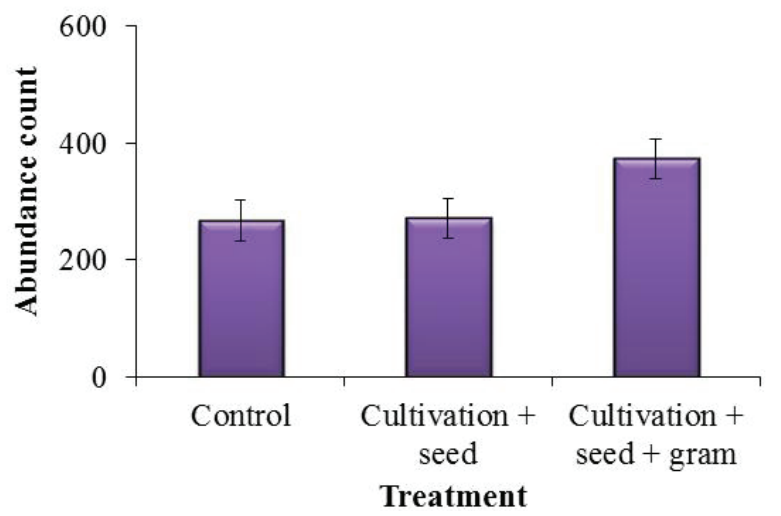

Figure 6. The response of invertebrate abundance to treatments ( \pm $\mathrm{SE})$. Gram = graminicide. Graphs show overall treatment responses across both sites and all years (untransformed data). Based on post-hoc Tukey's tests.

to be successful (Pywell et al., 2007). In our study, this was demonstrated by the lower sown wildflower cover observed in the treatment receiving cultivation with wildflower seeds only (treatment 2). By contrast, the cover of sown wildflowers in treatment 3 was significantly greater, and was likely to be due to the action of the graminicide reducing the competitive dominance of the grasses during the establishment year (2008) thus allowing the introduced perennial wildflowers to 
become established. As the grasses do provide some benefits, for example, by providing oviposition sites for butterflies, it was important that they were not eliminated completely and instead allowed to grow back after the wildflowers had become established, as occurred in 2009 and 2010 .

The benefits of establishing sown wildflowers within the existing buffer strips were highlighted by the positive responses observed for both insect pollinators and spiders. Bumblebee and butterfly abundance was highest in treatment 3 and probably due to a greater quantity of pollen and nectar foraging resources from the sown wildflowers. These results support previous studies that have demonstrated that the most effective method of creating suitable habitat for bumblebees, butterflies and other pollinating insects in arable buffer strips is to sow perennial wildflowers (Potts et al., 2007). Furthermore, over $80 \%$ of foraging visits by bumblebees and butterflies were made to the sown species Centaurea nigra (common knapweed), Lotus corniculatus (bird'sfoot trefoil) and T. pratense (RJ Blake, unpublished data), demonstrating the importance of these plants as key foraging resources (Carvell et al., 2011). Spider abundance was highest in treatment 3 and was probably due to the greater number of influorescences in these plots which attracted potential prey such as flies (Blake et al., in press). Furthermore, Rickers and Scheu (2005) demonstrated that increased habitat complexity reduced predation of juvenile wolf spiders by adult females through greater refuge provision. The abundance of spiders was lower in 2009, and was probably due to the autumn cut in 2008. Buffer strips are important refuges and overwintering habitats for spiders and other predatory invertebrates in agricultural fields (Thomas \& Marshall, 1999). These invertebrates tend to colonise crops in the spring, before moving into the buffer strips in late summer for subsequent breeding and overwintering. The timing of the cut, i.e. after the spiders had moved back into the buffer strips, probably led to a negative impact on the spider populations through detrimental changes in prey availability, microclimate, habitat structure and overwintering site potential (Bell et al., 2001).

\section{Conclusions}

Despite the introduction of agri-environment schemes, arable biodiversity continues to decline (Robinson \& Sutherland, 2002). Buffer strips represent a potentially key non-cropped habitat within arable landscapes to help meet the revised EU target of halting and reversing biodiversity loss in Europe by 2020. This study has highlighted how a combination of cultivation, sowing with wildflowers, and low dose graminicide use, can help enhance these existing commonly adopted areas and thus support the provision of multiple ecosystem services including pollination and pest control. Furthermore, differential management of the buffer strips can allow a range of taxa to be supported. For example, treating the outer portion of the grass buffer strips with a combination of cultivation with wildflower seeds, and graminicide, as in this study, can enhance overall spider abundance, and provide pollen and nectar foraging resources for bumblebees and butterflies (Potts et al., 2007; Blake et al., 2011). Leaving other areas of the buffer strips as grass (the inner two metres in this study) would allow an architecturally simple sward to develop to provide shelter and reproduction sites for invertebrates including butterflies and beetles, and ground-nesting birds.

\section{Acknowledgements}

This project was funded by the Biotechnology and Biological Sciences Research Council and Syngenta. We would like to thank the farmers for allowing access to their land for data collection.

\section{References}

Bell, J. R., Wheater, C. P. \& Cullen, W. R. (2001): The implications of grassland and heathland management for the conservation of spider communities: a review. Journal of Zoology, 255, 377-387.

Blake, R. J., Woodcock, B. A., Westbury, D. B., Sutton, P. \& Potts, S. G. (2011): Enhancing habitat to help the plight of the bumblebee. Pest Management Science, 67, 377-379.

Blake, R. J., Woodcock, B. A., Westbury, D. B., Sutton, P. \& Potts, S. G. (in press) Novel management to enhance spider biodiversity in existing grass buffer strips. Agricultural and Forest Entomology.

Butterfly Conservation, CEH, Defra \& Joint Nature Conservation Committee (2009): Populations of butterflies on farmland in England. Available from http://www.defra.gov.uk/environment/ biodiversity/documents/indicator/200904a1b.pdf. Date accessed 26 May 20122.

Carvell, C., Osborne, J. L., Bourke, A. F. G., Freeman, S. N., Pywell, R. F. \& Heard, M. S. (2011): Bumble bee species' responses to a targeted conservation measure depend on landscape context and habitat quality. Ecological Applications, 21, 1760-1771.

Feber, R. E., Smith, H. \& Macdonald, D. W. (1996): The effects on butterfly abundance of the management of uncropped edges of arable fields. Journal of Applied Ecology, 33, 1191-1205.

Gibson, C. W. D., Hambler, C. \& Brown, V. K. (1992): Changes in spider (Aranae) assemblages in relation to succession and grazing management. Journal of Applied Ecology, 29, 132-142.

Hofmann, M. \& Isselstein, J. (2004): Seedling recruitment on agriculturally improved mesic grassland: the influence of disturbance and management schemes. Applied Vegetation Science, 7, 193-200.

Klein, A. M., Vaissiere, B. E., Cane, J. H., Steffan-Dewenter, I., Cunningham, S. A., Kremen, C. \& Tscharntke, T. (2007): Importance of pollinators in changing landscapes for world crops. Proceedings of the Royal Society B-Biological Sciences, 274, 303-313.

Marshall, E. J. P., Brown, V. K., Boatman, N. D., Lutman, P. J. W., Squire, G. R. \& Ward, L. K. (2003): The role of weeds in supporting biological diversity within crop fields. Weed Research, 43, 77-89.

Natural England (2009): Agri-environment schemes in England 2009: A review of results and effectiveness. Available from http://www.naturalengland.org.uk/Images/AE-schemes09_tcm614969.pdf. Date accessed 11 October 2012.

Potts, S. G., Biesmeijer, J. C., Kremen, C., Neumann, P., Schweiger, O. \& Kunin, W. E. (2010): Global pollinator declines: trends, impacts and drivers. Trends in Ecology \& Evolution, 25, 345-353.

Potts, S. G., Westbury, D. B., Woodcock, B. A., Ramsay, A. J., Harris, S. J., Springate, S., Pywell, R., Meek, B., Carvell, C., Hulmes, L., Warman, L., Sparks, T., Cook, S. K. \& Henderson, I. G. (2007): Experiment 2 - Management of the non-cropped margin structure to maximise biodiversity. The SAFFIE Report. ADAS, Boxworth, UK.

Pywell, R. F., Bullock, J. M., Tallowin, J. B., Walker, K. J., Warman, E. A. \& Masters, G. (2007): Enhancing diversity of species-poor 
grasslands: an experimental assessment of multiple constraints. Journal of Applied Ecology, 44, 81-94.

Pywell, R. F., Warman, E. A., Carvell, C., Sparks, T. H., Dicks, L. V., Bennett, D., Wright, A., Critchley, C. N. R. \& Sherwood, A. (2005): Providing foraging resources for bumblebees in intensively farmed landscapes. Biological Conservation, 121, 479-494.

Rickers, S. \& Scheu, S. (2005): Cannibalism in Pardosa palustris (Araneae, Lycosidae): effects of alternative prey, habitat structure, and density. Basic and Applied Ecology, 6, 471-478.

Robinson, R. A. \& Sutherland, W. J. (2002): Post-war changes in arable farming and biodiversity in Great Britain. Journal of Applied Ecology, 39, 157-176.

Thomas, C. F. G. \& Marshall, E. J. P. (1999): Arthropod abundance and diversity in differently vegetated margins of arable fields. Agriculture Ecosystems \& Environment, 72, 131-144.

Robin Blake works as a Weed Control Biologist for Syngenta and manages a team investigating new and existing herbicides for use in soybean, cotton and rice crops. Previously he conducted a PhD at the University of Reading which focussed on novel methods to enhance plant and invertebrate biodiversity in existing grass buffer strips.
Duncan Westbury is a Senior Lecturer in the Institute of Science \& Environment at the University of Worcester. He has a strong background in applying ecological principles to habitat creation and management, with extensive research experience on the management of agro-ecosystems to support biodiversity whilst simultaneously supporting ecosystem services. Current research focuses on using wildflower forages to reduce methane production in dairy cows and the benefits of introducing wildflower strips in apple orchards with regards to the provision of pollination and pest regulation services.

Ben Woodcock is an Ecological Entomologist working at the NERC Centre for Ecology \& Hydrology, UK. He works on reconciling modern agricultural management with the maintenance of ecosystem services (pest control and pollination) and native biodiversity by developing applied management solutions. This has focussed mainly on the development of agri-environmental schemes in both arable and grassland systems.

Peter Sutton is a Senior Technical Expert working in the Ecological Risk Assessment group at Syngenta. He also leads the 'Environmental Stewardship' team which sponsors various collaborative research projects with particular emphasis on soil, water and biodiversity.

Simon Potts is Professor of Biodiversity and Ecosystem Services at the University of Reading. His research focusses on the relationships between land use, biodiversity and ecosystem function and how this impacts on society.

Similar articles that appeared in Outlooks on Pest Management include - 2008 I9(4) I73; $200920(3) 137$

\section{Take out a subscription to International Pest Control ... \\ $\ldots$ and get online access to the IPC archives back to January 2004 -- Free!}

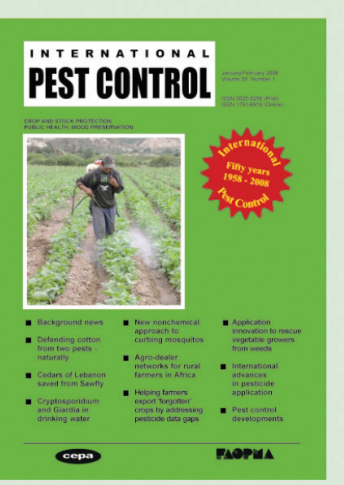

All subscribers have FREE online access to our fully searchable online archives, covering all issues from 2004 to date. The online licence for institutional subscribers covers all users at the subscription address.

All issues are now viewable in Flash-based 'pageflip' format see http://researchinformation. co.uk\#ipco

Complete the form opposite and fax or post back to:

The Subscription Manager, Research Information Ltd, Grenville Court, Britwell Road, Burnham, Bucks. SL1 8DF, UK.

Tel: +44 (0)1628 600499 Fax: +44 (0)1628 600488

Email: info@researchinformation.co.uk

Web: www.researchinformation.co.uk

\section{Subscription Order Form}

Please send me International Pest Control (six issues) for one year @

[ ]£156 (US\$312) Institutional

[ ] $£ 85$ (US\$170) Personal

[ ] $£ 60$ (US\$120) CEPAFAOPMA Member

Name / Job title

Dept:

Organisation:

Address:

Postcode:

Email:

[ ] Please send a proforma invoice

[ ] I enclose a cheque drawn on a UK bank

Please charge my:

[ ] Mastercard [ ] Visa [ ]Amex

Card no:

Expiry date: Security (CVV) digits:

Name on card

Signature: 